\title{
Literary Traditions of Mahtimkuli in Modern Turkish Poetry
}

\author{
Gaylieva Ogulbay Kurbanmuradovna \\ Doctor of Philological Sciences \\ Berdakh Karakalpak State University
}

(Poets in the example of S.Ibragimov, HamrakulAskar, K.Gurbannepsov works)

\section{ABSTRACT}

This article examines the problems of the literary impact of the works of a Turkmen poet of the XVIII century Maktymkuly Pyragy on the work of subsequent Turkic writers, and at the same time on the works of modern Uzbek, Karakalpak and Turkmen writers. Literary traditions and the development of Maktymkuly's work are also comparatively studied, especially in the lyrics of the Karakalpak poet I. Yusupov, the Uzbek poet H. Askarov and the Turkmen poet G. Gurbannepesov.

Keywords: poetry, lyrics, typology, literary influence, literary tradition

\section{INTRODUCTION}

Makhtimkuli is a poet of great prestige and respect in the literature of the Turkic peoples. In the long history, Makhtimkuli and other Turkmen poets were influenced by the works of Alisher Navoi or Zahiriddin Muhammad Babur and considered them their teachers. In the Uzbek and Karakalpak literature of the 20th century, there are many Turkic poets who wrote poems close to Makhtimkuli's tradition.

Literary critic K.Kurambaev studies the similarities and traditions in the form and content of the literature of the fraternal peoples on the example of the lyrical heritage of Alisher Navoi, Makhtimkuli, Abay, Ajniyaz, Berdak, Furkat and Andalip. And studying the continuation of the peculiarities of Makhtimkuli's work in Karakalpak poetry on the example of the poems of $\mathrm{I}$. Yusupov, who was faithful to the traditions of Makhtimkuli, he writes:: «After I. Yusupov, it became a tradition in Karakalpak literature to write poetry in the way of Makhtimkuli. There are many poets in modern Karakalpak poetry who imitated the poems of Makhtimkuli. Most of them are experienced poets. Here are some of them. T.Kabulov «Makhtimkuliga murojat»(Appeal to Makhtimkuli), U.Pirjanov «Bulmas»(It will not), J.Izbaskanov «Bulmasa»(If not), A.Utepbergenov «Bularmi»(Would it be), A.Ajiniyazov «Bular»(It will be)and U.Daniyarova's poems "Boshladi"(Began), "Bular sen"(Will be you) are a unique example of respect to the poetry of Makhtimkuli, a good example of literary similarity. In the poems we see a new interpretation of the themes written by Makhtimkuli».

Indeed, in Makhtimkuli, a unique rhythmic voice, like wisdom wrapped in wisdom, and many poetic factors used to influence the human psyche, attract artists. Among modern Uzbek and Karakalpak poets, there are those who imitated Makhtimkuli`s poem forms.Among them are Uzbek poets Halima Hudayberdieva, Muzaffar Ahmad, Hamroqul Askar, Abdumajid Azim, written during the years of independence; It is expedient to cite the poems of Karakalpak poets of 
different generations, such as S. Ibragimov, B. Genjemuratov.

For example, Makhtimkulihas a poem that was written in the form of dialogue «Turgil!» deydilar!» («Uygon deydilar»). We can compare his poemin terms of theme and contentto Karakalpak poet S.Ibragimov`s poem «Jabroiil farishta «Uki!» dedilar», written in April 2018 , dedicated to the poet B. Genjemuratov, then the harmony in them is clearly visible.. The poet S. Ibragimov himself brought us this poem from the house archives. This poem of the poet is formed on the basis of the plot, in which the dialogical form is widely used, the religious content is strong. For example, in S.Ibragimov:

In a dream an illusion came to him,

Handed something wrapped with cloth -

Sound is loud, said: «Read!»-

«I cannot read», - said Mukhammad

The words of the Qur'an came to the tongue -

He remembers going to the desert,

A pair of birds from above carried him away

They took him to a hill.

Now the words of Muhammad

The word of Allah will be-

To the heart of every fellow

He tried to convey the divine words.

\section{MATERIALS AND METHODS}

The poet's poem contains a mythical motif that Allah told the Prophet Muhammad to recite the verses of the Qur'an and introduce them to the people, and this content is compared to the divinity in the path of poetry. The poet is endowed with divinity by God, which is why he argues that he should form a sermon in his works and convey it to the people.Therefore, in the poem of $\mathrm{S}$. Ibragimov it is stated that «After the Prophet, the poet is a traveler of the world of meaning»:

Poet and priest after the Prophet

Passengers of this world-
If the poet interprets the world

The priest paints the white black. -As a result, when poets form more good deeds in their poems and become respected poets of the people, the idea that he is the target of perfection is reflected in the introductory part of the poem:

In Makhtumkuli:

I slept one night in the middle of the night,

Four horsemen came and said, "Get up!".

"We know we have the opportunity,

There are men out there, let's go. ".

Sixty horsemen came out of the rock,

"Muhammad!" they all greet,

Asked health and well-being,

"Don't stop, come on!" they said, -

In these poems, too, the motives of the divine being given to the poet by the prophets are formed in a wide range. In Makhtimkuli's poem, the lyrical protagonist's perfection through this divinity is formed in word magic. Therefore the poet:

Standing up, Magtymguly's eyes widened, What tunes have come to Serine,

It's been a long time coming,

«Uglan, God bless you!» said, -

he told, the events at the end of the poem are shown in a metaphorical way through their inner senses. In Makhtimkuli's understanding of the world is given through the motives of this divine perfection, in S. Ibragimov's ability to recognize the truth of life, injustice, good and evil, to say white is white, black is black, to understand life correctly, this is firstly the divine perfection of the poet. he is told that he is aware that he will be more knowledgeable. Therefore, the poet $\mathrm{S}$. Ibragimov:

This is the sound of the word "read"

People who have judged their lives -

What will happen to the people if we remain silent?,

If we don't tell them, what will be the punishment?

Fire both in heaven and on earth - 
Where people live

If we do not hear the word "read" -

Karakalpak people will have lost us. ,-

In the poem, he describes in words the artistic love of each poet's works. For him, the poet is more "Uki!"(read) emphasizes the rhetorical direction by applying command inclination. Therefore, we see that in the lyrical poems of S. Ibragimov developed classical traditions, that is, the traditions of Makhtumkuli, and tried to update it in terms of form and content.The reason is that $\mathrm{S}$. Ibragimov's poem is characterized by a new form of formal research, ie the use of lowercase letters in the beginning of the verses, the unequal number of syllables in the verses, the free use of rhyme, the widespread use of modern methods of description.Makhtumkuli's "“"Turgul!" deydiler!" in the poem entitled fourcouplet in the traditional form, the first couplet a$\mathrm{b}-\mathrm{a}-\mathrm{b}$; the rest are rhymed in the form v-v-v-b. It can therefore be seen that the artistic form of the classical traditions has been renewed in modern Karakalpak lyric poetry.Therefore, the poet S. Ibragimov:

Makhtumkuli said that the sun,

The good deeds of the people

Comes out to see,

He turns away from evil ways, -

In these verses, Makhtumkuli developed from the didactic-traditional point of view. The idea that one should strive for good and stay away from evil comes to the fore as the main idea of the poem.

The poem "Turkmanning" by the Uzbek poet Hamrakul Askar, who mastered the literary traditions of Makhtumkuli, begins as follows:

Moon, neighborhood of stars, wide desert of sand,

A Turkmen has a loving grandmother named the Sun.

His word is sharpened like a sword, he cried for my homeland,
The Turkmen have a nightingale grandfather named Makhtumkuli

Then the poet describes other qualities, characteristics, freedom of the Turkmen people.

God gave the Turkmen people black and red gold,

The Turkmen have the light that

illuminates the darkness.

Scattered all over the world, now the way is open,

There is a Turkmen in the circle of friends.

The thought and intonation in this line are mainly in the poem "Turkmanning" by the great Turkmen poet Makhtumkuli:

Between Ceyhan and the Caspian Sea,

Turkmen people work on the desert.

The flower buds are black, they are my pupil,

Turkmen`s flood from the Black Mountain

Makhtumkuli's poem also attracted the attention of the Karakalpak national poet I. Yusupov, who lived in the XX century. In his poem "Tuylargaulansintuyiturkmanning":

Success flower grew in the field,

Our happiness was brighter than the sun,

An example of screaming again,

Makhtumkuli was the word of the Turkmen

\section{RESULTS AND DISCUSSIONS}

The author continues the literary traditions of his mentor. It depicts the spread of Makhtumkuli's works to the Karakalpak people in the 20th century, the artistic translation of his books and the gift to readers, and at the end of the verse the next verse of the poet's poem is repeated in this form. Therefore, the novelty of content and form in the poem is recommended.

Makhtumkuli's poem "Turkmennin" also influenced the twentieth-century Turkmen poet Kerim Gurbannepesov to write a poem "Turkmennin" in the form of amurabba.In the poem, the first two lines of Makhtumkuli's poem 
are taken as epigraphs, and the poem is written in 11 syllables, and in the fourth line of each verse of the poem the word "turkmennin" is repeated in radif form:

There is a wonderful dawn on the earth, The light of the dawn shines on the earth.

Sunset, you listen to the song of the sun There is a language of Turkmen.

In the poem, the poet depicts the peoples of the world living in brotherhood and harmony with each other, the Eastern culture is known to the world through the image of Bakhshi, and the conclusion at the end of the poem gives a strong rhythm and intonation to the thought.

The above typological feature can be seen in the continuation of the literary traditions of the poets of the nation in question, and in their ability to enrich them with new content and form.

In short, we consider it necessary to make a special study of the literary influence of Makhtumkuli's literary traditions on the poets of modern Turkic peoples.

\section{REFERENCE}

1.Kurambayev K. Literary process. Creativity is your responsibility. Literature relations. - Tashkent: Chulpon, 2009.

2.Ibragimov S. Report this website"they said. 2018-jil, April. YY archivinenese Aling'an spoons.

3.Magtymguly. Works I volume of iygyndysy. A.: Turkmenistanyň Ylymlar akademiýasynyň National golýazmalar Institute, 2012.

4.Ibragimov S. Groin with pus. - Nekis: Knowledge, 2016.

5.Hamrakul Askar. The river. -Tashkent: publishing house of the National Library of Uzbekistan named after Alisher Navoi, 2006.

K. Don't wake up. - Ashgabat, 1995. - What? 278. http: / / ene dilim7.Mextumkuli. Works. - Tashkent: Akademnashr, 2013.

8.Yusupov I. Keo'dynya in keildilde. -Nekis: From Karakalpakstan, 1989.

9.Гурбаннепесов.com you know what?

10. Keruenov T.A. The Image Of Torebekkhanim And Legends About Her In the Work of Ajiniyaz
Poet. International Journal of Advanced Science and Technology Vol. 29, No. 8, (2020), pp.33573359

11.Jepbarova S. Bakshi and demonological characters in the poem "Ashiq Na'jep" (According to the Turkish versions examples of the poem"Ashiq Na'jep").

International Journal of Advanced Science and Technology Vol. 29, No. 8, (2020), pp.3261-3266 